\title{
MENGUKUR WORK LIFE BALANCE, STRES KERJA DAN KONFLIK PERAN TERHADAP KEPUASAN KERJA PADA WANITA PEKERJA
}

\author{
Lukman Cahyadi, Desy Prastyani \\ Program Studi Manajemen Fakultas Ekonomi dan Bisinis Universitas Esa Unggul \\ Jalan Arjuna Utara No 9 Kebon Jeruk Jakarta 11510 \\ lukman.cahyadi@esaunggul.ac.id
}

\begin{abstract}
The purpose of this study is to see how the effects of Work-life balance on job satisfaction of women workers were studying, how the effects of stress work on job satisfaction women workers were studying, how the effects of role conflict on job satisfaction and how the effects of work-life balance, Job Stress, role conflict on job satisfaction women workers were studying. The samples on this research are 100 respondents. The respondents are the Women Workers were studying In Private University On West Jakarta. The methods of analyze in this research is linear regrestion. The results showed that simultaneous Work-life balance, Job Stress, and Role conflict on Job Satisfaction on Women Workers were studying In Private University on West Jakarta. Partially work-life balance, job stress, and role conflict on job satisfaction on women workers were studying In Private University on West Jakarta and variable work-life balance as a dominant variable.
\end{abstract}

Keywords: Work-life balance, Work Stress, Role Conflict and Job Satisfaction

\begin{abstract}
Abstrak
Tujuan penelitian ini untuk melihat bagaimana pengaruh Work-life balance terhadap kepuasan kerja wanita bekerja yang kuliah, bagaimana pengaruh stres kerja terhadap Kepuasan Kerja wanita bekerja sambil kuliah, bagaimana pengaruh konflik peran terhadap Kepuasan Kerja, dan bagaimana pengaruh Work-life balance, stres kerja dan konflik peran terhadap kepuasan kerja wanita bekerja yang kuliah. Jumlah sampel yang digunakan dalam penelitian ini sebanyak 100 responden. Responden penelitian ini adalah wanita pekerja yang kuliah di Universitas Swasta di wilayah Jakarta Barat. Metode analisis yang digunakan dalam penelitian ini adalah regresi linier berganda. Hasil penelitian menunjukan berpengaruh secara simultan variabel work-life balance, stres kerja dan konflik peran terhadap kepuasan kerja khususnya pada wanita pekerja yang kuliah di Universitas Swasta di wilayah Jakarta Barat serta variabel work-life balance, stres kerja dan konflik peran secara parsial mempengaruhi kepuasan kerja wanita pekerja yang kuliah pada Universitas Swasta di Jakarta Barat dan variabel work-life balance sebagai variabel dominan.
\end{abstract}

Kata Kunci: work-life balance, stres kerja, konflik peran dan kepuasan kerja

Pendidikan merupakan aspek penting bagi setiap negara, terutama bagi negara berkembang seperti negara Indonesia. Terlebih dalam dunia kerja, dimana banyak perusahaan yang menuntut pegawainya berpendidikan minimal sarjana, sehingga individu berusaha untuk menempuh pendidikan yang tinggi (Taslima dan Tjjala, 2008). Kesempatan untuk mendapat pekerjaan akan lebih mudah jika seorang pencari kerja memiliki latar belakang pendidikan tinggi. Hal tersebut terjadi karena melalui pendidikan, individu akan mampu meningkatkan kualitas sumber daya manusia. Sumber daya manusia di perusahaan dikatakan yang utama sebab sumber daya manusia itu sendiri yang menentukan kemana arah dan tujuan dari perusahaan (Ganapathi, 2016). Oleh karenanya seorang tenaga kerja harus menempuh pendidikan di perguruan tinggi atau universitas. Pendidikan tinggi yang berkualitas dengan hasil yang memuaskan sangat diharapkan oleh seluruh mahasiswa.

Banyak faktor yang melatar belakangi mahasiswa yang kuliah sambil bekerja. Faktor yang pertama yaitu pengaruh dari kekurangan biaya pendidikan, Faktor pendidikan memiliki andil yang cukup besar terhadap meningkatnya partisipasi wanita dalam pasar kerja. 
Sedangkan faktor lainya yaitu adanya keinginan mahasiswa untuk mencari pengalaman serta mengisi waktu luang menyebabkan sebagian mahasiswa memilih untuk kuliah sambil bekerja (Purwanto, Syah dan Rani 2013). Mahasiswa memutuskan untuk bekerja karena terkadang memiliki tuntutan untuk memenuhi kebutuhan yang lebih besar dari pada pemasukan yang didapatkan (Fitroh, 2015).

Adapun masalah atas kurangnya keseimbangan antara kehidupan pekerjaan dan kehidupan diluar pekerjaan seperti keluarga, pendidikan dan sosial yang terjadi pada wanita yang bekerja yang kuliah pada universitas swasta di Jakarta Barat. Peneliti melakukan penyebaran kuesioner pada saat pra survey kepada 20 wanita pekerja yang kuliah di Universitas tersebut. Peneliti menemukan 19 dari 20 responden tersebut merasa setuju dengan pernyataan Sulit membagi waktu dalam mengerjakan tugas perusahaan dan tugas perkuliah. Hal ini menunjukan bahwa kurangnya keseimbangan dalam segi waktu yang membuat wanita pekerja yang kuliah memiliki banyak tanggung jawab dalam pekerjaan dan perkuliahanya. Tidak hanya itu wanita yang bekerja yang kuliah tersebut juga merasakan tekanan terhadap tuntutan perusahaan yang mempengaruhi kehidupan dalam pendidikan maupun pribadi. Rendahnya tingkat keseimbangan kehidupan kerja dan kehidupan diluar pekerjaan dapat menimbulkan stres pada karyawan. Saragih dan Rizkiyani (2012) menambahkan bahwa masalah stres kerja di dalam organisasi perusahaan menjadi gejala yang penting diamati sejak mulai timbulnya tuntutan untuk efisien di dalam pekerjaan. Akibat adanya stres kerja tersebut yaitu orang menjadi nervous, merasakan kecemasan yang kronis, peningkatan ketegangan pada emosi, proses berpikir dan kondisi fisik individu. Selain itu, sebagai hasil dari adanya stres kerja karyawan mengalami beberapa gejala stres yang dapat mengancam dan mengganggu pelaksanaan kerja mereka, seperti : mudah marah dan agresif, emosi yang tidak stabil, sikap tidak mau bekerja sama, perasaan tidak mampu terlibat, dan kesulitan dalam masalah tidur.

Pergeseran budaya, gaya hidup yang tinggi dan perkembangan status sosial, dimana saat ini peran wanita telah bergeser dari peran tradisional menjadi peran ganda yakni sebelumnya hanya berperan dalam keluarga, kini mempunyai peran lain yaitu peran sebagai mahasiswa dan juga peran sebagai wanita yang harus bekerja. Adanya konflik peran mempunyai konsekuensi atau dampak terhadap karyawan, utamanya pada tingkat kepuasan kerja (Churiyah, 2007). Kuliah sambil bekerja memunculkan tantangan tersendiri bagi setiap individu, seperti proses perkuliahan dan pekerjaan yang menyita waktu energi. Tantangan lainya adalah ketika tugas di masing-masing tempat tidak mencapai hasil yang maksimal, karena manajemen waktu yang kurang baik. Tidak menutup kemungkinan, beban tugas kantor dan kuliah yang sama-sama penting membuat kelelahan secara fisik dan psikologis. Hal ini cenderung akan memunculkan emosi yang negatif dan sensitif maka konflik dengan orang-orang sekitar akan terjadi. Stres dan konflik akan berdampak pada kepuasan kerjanya. Kepuasan kerja karyawan merupakan faktor yang sangat diperhatikan. Karyawan yang tidak merasakan kepuasan kerja akan mengakibatkan pekerjaannya terhambat sehingga ia tidak memiliki selera untuk menyelesaikan tugasnya dan berdampak terhadap komitmen dirinya terhadap organisasi. Sehingga dapat disimpulkan bahwa, demi tujuan perusahaan dalam menjalankan operasinya dengan maksimal, perusahaan harus mampu memperhatikan keseimbangan kerja dan kehidupan setiap karyawan serta tingkat stress kerja karyawan agar tidak menimbulkan konflik demi terciptanya kepuasan kerja karyawan. Karyawan yang puas akan memberikan dampak yang positif bagi perusahaan untuk jangka panjang. Hal ini menunjukkan bahwa indeks kepuasan kerja karyawan dapat dijadikan tolak ukur untuk melakukan tindakan korektif yang diperlukan. Penelitian ini memiliki tujuan yaitu mengukur pengaruh work life balance, stress kerja, konflik peran terhadap kepuasan kerja seorang karyawati yang merangkap sebagai mahasiswi di universitas swasta, sekaligus untuk mengetahui persoalanpersoalan yang terjadi antara persoalan perkuliahan dan juga pekerjaan terhadap wanita pekerja yang berkuliah. 
Schermerhorn dalam Ramadhani (2013) mengungkapkan bahwa work-life balance adalah kemampuan seseorang untuk menyeimbangkan antara tuntutan pekerjaan dengan kebutuhan pribadi dan keluarganya. sebagai instrumen dalam memberikan perhatian yang seimbang antara domain kerja (working domain) dengan domain non-kerja (non-working domain). Hal ini juga selaras dengan pendapat Frame dan Hartog dalam Moedy (2013) yang memaparkan bahwa workIfe balance berarti karyawan dapat dengan bebas menggunakan jam kerja yang fleksibel untuk menyeimbangkan pekerjaan atau karyanya dengan komitmen lain seperti keluarga, hobi, seni, dan tidak hanya fokus terhadap pekerjaannya. Karyawan yang bekerja pada organisasi swasta atau perusahaan swasta lebih memiliki employee engagement dan komitmen organisasional yang lebih tinggi dari pada karyawan yang bekerja pada organisasi publik atau perusahaan milik Negara (Anindita dan Cahyadi, 2020). Fisher (2001) sendiri memiliki gambaran berbeda dengan yang lain, dia menjabarkan definisi work-life balance dengan beberapa komponen. Fisher (2001) menyatakan bahwa work-life balance merupakan suatu stressor kerja yang meliputi empat komponen penting, yaitu Time, Strain, Energy, Aim. Ramadhani (2013) menjelaskan bahwa stres kerja adalah suatu kondisi dimana terdapat satu atau beberapa faktor ditempat kerja yang berinteraksi dengan pekerja sehingga menggangu kondisi fisiologis dan perilaku. Ditambahkan pula dalam penelitian yang dilakukan oleh Rivai dan Sagala (2009) stres kerja adalah suatu kondisi ketegangan yang menciptakan adanya ketidakseimbangan fisik dan psikis, yang mempengaruhi emosi, proses berfikir, dan kondisi seorang karyawan. Sedangkan menurut Robbins dan Judge (2013) stress adalah suatu kondisi dinamis dimana seorang individu dihadapkan dengan peluang, tuntutan, atau sumber daya yang terkait dengan apa yang dinginkan individu lain dan yang hasilnya dipersepsikan tidak pasti atau penting. Luthans (2002) mendefinisikan konflik peran sebagai suatu posisi yang memiliki harapan untuk berkembang dari norma yang dibangun. Seorang individu akan mengalami konflik peran dalam organisasi jika yang bersangkutan menerima peran yang tidak sesuai dengan perilaku peran yang tepat, hal ini sesuai dengan pernyataan Tidd dan Friedman (2002) konflik peran adalah situasi dimana ada perbedaan tuntutan dalam diri seorang karyawan karena ada perbedaan peran yang menyebabkan perbedaan tindakan yang harus dilakukan. Konflik peran menyebabkan tekanan pada diri karyawan yang mengharuskan pada perbedaan tindakan yang diambil yang akan berpengaruh terhadap keadaan karyawan secara psikologis. Prihatsanti dalam Wibowo, et. al (2015) kepuasan kerja merupakan indikator dasar keberhasilan individu di tempat kerja yang telah dicapai dalam mempertahankan hubungan antara dirinya dan lingkungan kerja, yang terdiri dari kepuasan intrinsik dan ekstrinsik Robbins dan Judge (2013), juga menuturkan bahwa, seorang individu yang memiliki tingkat kepuasan kerja yang tinggi, akan memiliki perasaan yang positif terhadap pekerjaannya, dan sebaliknya, seorang individu yang memiliki tingkat kepuasan kerja yang rendah, akan memiliki perasaan yang negatif terhadap pekerjaannya.

\section{Hubungan Stres Kerja terhadap Kepuasan Kerja}

Atheya dan Arora (2014) mendefinisikan stres di tempat kerja sebagai kondisi yang timbul dari interaksi antara orangorang dengan pekerjaan mereka, yang mana ditandai dengan adanya perubahan pada orang yang memaksakan diri mereka untuk menyimpang dari fungsi normal mereka.. Hal ini bermakna bahwa stres kerja yang dialami oleh karyawan dapat mempengaruhi apa yang mereka rasakan baik itu menyangkut pekerjaan maupun hasil yang mereka terima (Wibowo et. al, 2015). Penelitian yang dilakukan oleh Wibowo et.al, (2015) menunjukan stres kerja berpengaruh negatif dan signifikan terhadap kepuasan kerja yang artinya semakin tinggi stres kerja makan semakin rendah kepuasanya. Timbulnya stres dan depresi pada akhirnya akan berdampak buruk pada pekerjaan itu sendiri dan menyebabkan produktivitas yang rendah (Wharton, 2009). 


\section{Hubungan Konflik Peran terhadap Kepuasan Kerja}

Menurut Tidd and Friedman (2002) menyatakan konflik peran adalah situasi dimana ada perbedaan tuntutan dalam diri seorang karyawan karena ada perbedaan peran yang menyebabkan perbedaan tindakan yang harus dilakukan. Penelitian yang dilakukan oleh Agustina (2009) menunjukan bahwa konflik peran berpengaruh negatif dan signifikan terhadap Kepuasan Kerja yang artinya semakin tinggi konflik peran semakin rendah kepuasan kerjanya.

\section{Hubungan Work-life balance terhadap Kepuasan Kerja}

Berdasarkan penelitian yang dilakukan Kanwar et al. (2009) menyatakan bahwa dari hasil penelitian diperoleh bahwa variabel Worklife balance (variabel independen) yang dominan mempengaruhi kepuasan kerja $(Y)$, maka dengan demikian adanya pengaruh variabel dominan work-life balance terhadap kepuasan kerja.

\section{Metode Penelitian}

Penelitian ini dilakukan pada mahasiswa yang kuliah sambil bekerja di salah satu Universitas Jakarta Barat tentang analisis work life balance, stres kerja dan konflik peran terhadap kepuasan kerja. Data yang digunakan dalam penelitian ini adalah diperoleh dengan penyebaran kuesioner.
Populasi dalam penelitian ini adalah mahasiswi eksekutif yang kuliah sambil bekerja yang ditemukan oleh peneliti di perguruan tinggi swasta di Jakarta Barat dengan jumlah 3.267 orang. Sedangkan jumlah keseluruhan responden dalam penelitian ini adalah 100 responden.

Purposive sampling yang diginakan dalam pengambilan sampel ini dilakukan jika peneliti melakukan pengambilan sampel berdasarkan keputusan dari peneliti sendiri berdasarkan kriteria-kriteria yang ditetapkan sendiri oleh peneliti sepanjang unsur-unsur yang akan diteliti merupakan anggota populasi (Sugiyono, 2008). Berikut kriteria yang ditentukan peneliti, yaitu:

1. Mahasiswi Aktif yang kuliah sambil bekerja di perguruan swasta di Jakarta Barat.

2. Pekerja dengan masa kerjanya lebih dari 2 tahun.

3. Mahasiswi yang pekerja berusia $20-45$ tahun

\section{Hasil dan Pembahasan}

Pada tahap pertama peneliti melakukan analisis berdasarkan Faktor memilih kuliah sambil bekerja dari jumlah responden sebanyak 100. Berikut merupakan jumlah data responden berdasarkan Faktor memilih kuliah sambil bekerja.

\section{Tabel 1}

Faktor Bekerja Sambil Kuliah

$\begin{array}{ll}\text { Alasan Bekerja Sambil Kuliah } & \text { Jumlah } \\ \text { Financial } & 18 \\ \text { Keinginan Pribadi } & 26 \\ \text { Jenjang Karir } & 56 \\ \text { Total } & \mathbf{1 0 0}\end{array}$

Dari Tabel diatas, dapat dilihat bahwa responden yang paling dominan adalah faktor terhadap Jenjang Karir sebesar $56 \%$ atau sebanyak 56 responden, dan responden yang paling sedikit yaitu terhadap faktor financial sebesar $18 \%$ atau sebanyak 18 responden.

Pada tahap Kedua, peneliti melakukan analisis berdasarkan status dari jumlah responden sebanyak 100 . Berikut merupakan jumlah data responden berdasarkan status dari wanita pekerja yang kuliah di perguruan tinggi swasta di Jakarta Barat.

Dari Tabel 2 dapat dilihat bahwa responden yang paling banyak dalam penelitian ini adalah wanita yang belum menikah sebesar $73 \%$ atau sebanyak 73 responden dan responden yang paling sedikit dalam penelitian ini adalah wanita yang sudah menikah sebesar $27 \%$ atau sebanyak 27 responden 
Tabel 2

\section{Status Responden}

\begin{tabular}{ll}
\hline Status & Jumlah \\
\hline Menikah & 27 \\
Belum Menikah & 73 \\
Total & $\mathbf{1 0 0}$ \\
\hline
\end{tabular}

Pada tahap ketiga peneliti melakukan analisis mengenai Pekerjaan dari jumlah responden sebanyak 100 . Berikut merupakan jumlah data responden berdasarkan Pekerjaan dari Wanita pekerja yang kuliah di perguruan tinggi swasta Jakarta Barat.
Tabel 3 Pekerjaan

\begin{tabular}{ll}
\hline Pekerjaan & Jumlah \\
\hline Karyawan Swasta & 91 \\
Wiraswasta & 9 \\
PNS & - \\
Total & $\mathbf{1 0 0}$ \\
\hline
\end{tabular}

Uji $F$ digunakan untuk menguji pengaruh variabel independen yaitu Work-life balance $\left(X_{1}\right)$, Stres kerja $\left(X_{2}\right)$ dan Konflik peran $\left(X_{3}\right)$ terhadap variabel dependen yaitu Kepuasan kerja (Y) secara bersama-sama. Berikut ini adalah hasil perhitungan uji $F$ menggunakan software statistik.

\begin{tabular}{lllllll}
\hline Model & & Sum of Squares & Df & Mean Square & F & Sig. \\
1 & Regression & 211,317 & 3 & 70,439 & 14,175 &, $000 \mathrm{~b}$ \\
& Residual & 477,043 & 96 & 4,969 & & \\
& Total & 688,360 & 99 & & & \\
\hline
\end{tabular}

Hasil perhitungan tabel dengan menggunakan uji $\mathrm{F}$ diperoleh $\mathrm{F}$ hitung sebesar 14,175 dengan tingkat signifikan 0,000. Karena nilai probabilitas kurang dari 0,05 yaitu $(0,000<0,05)$. Maka model regresi dapat digunakan untuk hipotesis bahwa diduga variabel work-life balance, stres kerja dan konflik peran secara bersama-sama berpengaruh terhadap kepuasan kerja pada wanita pekerja yang kuliah di perguruan tinggi swasta di Jakarta Barat dapat diterima kebenarannya.

\section{Uji t}

Uji $t$ digunakan untuk menguji pengaruh variabel independen yaitu Work-life balance $\left(\mathrm{X}_{1}\right)$, Stres kerja $\left(\mathrm{X}_{2}\right)$ dan konflik peran $\left(\mathrm{X}_{3}\right)$ terhadap variabel dependen yaitu Kepuasan Kerja $(Y)$ secara parsial atau sendirisendiri, dapat dilihat dari tabel dibawah ini:

Tabel Uji t

\begin{tabular}{lllllll}
\hline \multicolumn{1}{c}{ Model } & \multicolumn{2}{c}{ Unstandardized Coefficients } & \multicolumn{2}{c}{ Standardized Coefficients } \\
1 & B & Std. Error & \multicolumn{2}{c}{ B } & Sig. \\
(Constant) & 30,748 & 4,684 & 6,564 & & \\
Work-life balance &, 271 &, 066 &, 354 & 4,129 &, 000 \\
Konflik Peran &,- 407 &, 123 &,- 281 & $-3,298$ &, 001 \\
Stres Kerja &,- 241 &, 085 &,- 244 & $-2,846$ &, 005 \\
\hline
\end{tabular}

\section{Work-life balance}

Hasil analisisnya menunjukkan bahwa Variabel Work-life balance $\left(\mathrm{X}_{1}\right)$ memiliki nilai signifikan $0,000<0,05$ secara parsial berpengaruh positif dan signifikan terhadap kepuasan kerja pada wanita pekerja yang kuliah.

\section{Stres Kerja}

Hasil analisisnya menunjukkan bahwa Variabel Stres kerja memiliki nilai signifikan $0,005<0,05$ secara parsial berpengaruh negatif dan signifikan terhadap kepuasan kerja pada wanita pekerja yang kuliah.

\section{Konflik Peran}

Hasil analisisnya menunjukkan bahwa Konflik peran (memiliki nilai signifikan 0,001< 
0,05 secara parsial berpengaruh negatif dan signifikan terhadap kepuasan kerja pada wanita pekerja yang kuliah

\section{Pengaruh Work-life balance Terhadap Kepuasan Kerja}

Hasil penelitian didapatkan work-life balance berpengaruh signifikan terhadap kepuasan kerja. Artinya apabila setiap perusahaan ingin meningkatkan Kepuasan Kerja pada pekerja wanita yang kuliah, perlu memperhatikan butir-butir indikator dari WorkIfe balance yang terdiri dari Kerja paruh waktu, yaitu perusahaan perlu menyediakan lebih banyak kerja paruh waktu dengan jam atau shift yang lebih sedikit atau penyusunan pembagian kerja untuk seluruh karyawan dimana hal ini dilihat dari nilai indeks yang paling besar.

\section{Pengaruh Stres Kerja Terhadap Kepuasan Kerja}

Hasil penelitian didapatkan Stres Kerja berpengaruh signifikan terhadap kepuasan kerja Wanita pekerja yang kuliah. Hasil penelitian ini mendukung dan memperkuat penelitian Afrizal et.al (2014) dimana penelitian tersebut menunjukan bahwa stres kerja berpengaruh negatif dan signifikan yang artinya semakin tinggi stres kerja makan kepuasan kerjanya akan menurun.

\section{Pengaruh Konflik Peran Terhadap Kepuasan Kerja}

Hasil penelitian didapatkan Konflik Peran berpengaruh signifikan terhadap kepuasan kerja Wanita pekerja yang kuliah. Hasil penelitian ini mendukung dan memperkuat penelitian Agustina (2009) dimana penelitian ini menunjukan adanya pengaruh antara konflik peran terhadap kepuasan kerja.

\section{Pengaruh Work-life balance, Stres dan Konflik Peran Terhadap Kepuasan Kerja}

Hasil penelitian didapatkan Work-life balance, stres kerja dan konflik peran secara bersama-sama berpengaruh signifikan terhadap kepuasan kerja Hal ini berarti bahwa ada hubungan yang signifikan dari Work-life balance, stres kerja dan konflik peran terhadap kepuasan kerja. variabel work-life balance menggunakan indikator Kerja paruh waktu dimana hal ini dilihat dari nilai indeks yang paling besar. Cuti harian, dimana hal ini dilihat dari indeks yang paling tinggi. Mobilitas pekerjaan dimana hal ini dilihat dari indeks yang paling tinggi. Indikator stres kerja Dukungan Sosial dilihat dari nilai indeks yang paling tinggi. konflik peran dilihat dari nilai indeks yang paling besar. Beban kerja dilihat dari nilai indeks yang paling tinggi. Idikator konflik peran dilihar dari tuntutan tugas dilihat dari nilai indeks yang tinggi.sibuk dengan pekerjaan dilihat dari nilai indeks yang tinggi. Konflik komitmen dan tanggu jawab terhadap keluarga dilihat dari nilai indeks yang tinggi. Hasil penelitian ini mendukung dan memperkuat penelitian I Made Devan Ganapathi (2016). Dari hasil pengujian, untuk meningkatkan kepuasan kerja para wanita pekerja dan juga melakukan kuliah maka perusahaan ditempat bekerja memperbaiki atau mengatasi work-life balance seperti kerja paruh waktu, cuti harian dan mobilitas pekerjaan sehingga mendapatkan keterampilan atau pengetahuan yang luas di dalam menyelesaikan pekerjaan ataupun tugas didalam kampus.

\section{Kesimpulan}

Dari hasil pengolahan dan menganalisa pembahasan dalam penelitian ini, dapat disimpulkan beberapa poin-poin penting yaitu jika faktor-faktor seperti tingkat kerja paruh waktu, cuti harian dan mobilitas pekerjaan dapat diperbaiki maka keseimbangan kehidupan kerja pada pekerja wanita pekerja yang kuliah semakin seimbang dan semakin tinggi pula kepuasan kerjanya selain itu perusahaan juga harus memperhatikan dukungan sosial, konflik peran dan beban kerja maka stres kerja akan menurun. Hasil penelitian menunjukan work-life balance merupakan variabel dominan terhadap kepuasan kerja yang artinya work-life balance sangat penting pada wanita pekerja yang sedang kuliah

\section{Daftar Pustaka}

Anindita, R., \& Cahyadi, L. (2020). Aplikasi Model Rasch dalam Mengukur Komitmen Dosen. JMSP (Jurnal 
Manajemen

dan

Pendidikan), 4(3), 220-231.

Atheya, R., \& Arora, R. 2014. Stress and its brunt on employee's work-life balance (wlb): A conceptual study. IOSR Journal Of Humanities And Social Science (IOSR-JHSS). 19(03),57-62

Churriyah, Madziatul. 2017. Pengaruh konflik peran terhadap Kepuasan kerja Perawat serta Komitmen pada organisasi. Jurnal Economics and Business. Vol 3, No.1

Fisher, G.G. 2001. Work/Personal Life Balance: A Construct Development Study. ProQuest Dissertations and Theses.

Fitroh, Agung. 2015. Self Managemen pada mahasiswa yang kuliah sambil bekerja. Jurnal Psikologi.

Ganapathi, I Made D. 2016. Pengaruh Worklife balance terhadap Kepuasan Kerja Karyawan. Ecodemica. Vol.4. No.1

Kanwar, Y. P. S., Singh, A.K., Kodwani, A.D. 2009. Work-life balance and Burnout As Predictors of Job Satisfaction in The ITITES Industry. The Journal of Business Perspective. Vol 13, No. 2.

Luthans, Fred, 2006. Organżational Behaviour. Tenth Edition. McGraw-Hill Companies Inc.

Moedy, Dinda Mega Rulita. 2013. Analisis work-life balance, Keinginan Untuk Meninggalkan Organisasi, Kepenatan (Burnout) dan Kepuasan Kerja Pada Dosen Universitas Atma Jaya Yogyakarta. E-Journal Universitas Atma Jaya Yogyakarta.

Purwanto, Hadi. Syah, Nurhasan. Rani, G. Iskandar. Perbedaan hasil belajar mahasiswa yang bekerja dengan tidak bekerja program studi pendidikan teknik bangunan jurusan teknik sipil FTUNP.jurnal teknik bangunan. Vol.1.No. 1.
Ramadhani, Malika. 2013, Analisis Pengaruh Keseimbangan Kehidupan-Kerja Terhadap Kesuksesan Karir (Studi pada Karyawan PT. Asuransi Jiwa Generali Indonesia). Jurnal FEB Universitas Brawijaya Malang.

Rivai, Veithazal. Dan Sagala, Ella, Jauvani. 2009. Manajemen Sumber daya Manusia dari Teori ke Praktik. Jakarta: PT Raja Grafindo

Robbins, S.P., dan Judge, T.A. 2013. Organżational Behavior. England: Pearson Education Limited.

Saragih, Susanto dan Rizkiyani, Dwi. 2012. Stres Kerja dan motivasi kerja pada petugas lembaga permasyarakatan. Jurnal Manajemen. Vol. 12. No. 1.

Saragih, Susanto dan Rizkiyani, Dwi. 2012. Stres Kerja dan motivasi kerja pada petugas lembaga permasyarakatan. Jurnal Manajemen. Vol. 12. No. 1.

Taslima, Yulifa dan Tjalla, Awaluddin. 2008. Hubungan Orientasi Belajar Denganh Motivasi Berprestasi Mahasiswa Psikologi Gunadarma. Jurnal Psikologi.

Tidd, Simon., Raymond A., Friedman. 2002. "Conflict Style and Coping with Role Conflict : An Extention of The uncertainty Model of Work Stress".

Wibowo, I.G.P., Riana, G., Putra, M.S. 2015. Pengaruh Stres Kerja terhadap Kepuasan Kerja dan Komitmen Organisasional Karyawan. E-Jurnal Ekonomi dan Bisnis Universitas Udayana 4.02. pp: 125-145. 